\title{
Editorial: parasitic helminths in Latin America and the Caribbean
}

\author{
C. Fernández* \\ Cátedra de Inmunología, Facultad de Química, Universidad de la \\ República, Av. Alfredo Navarro 3051, Montevideo 11600, Uruguay
}

(Received 13 November 2016; Accepted 16 January 2017)

This issue of the Journal of Helminthology includes a special topic dealing with six reviews on various aspects of parasitic helminths in Latin America and the Caribbean (LAC). The majority refer to helminths infecting aquatic hosts and range from fundamental questions to epidemiology and control challenges.

Helminth infections are highly prevalent over large areas of LAC, where they cause severe morbidity and seriously affect the efficiency of food production systems. As in other regions of the world, they are a hallmark of poverty and, furthermore, a major hindrance to development (Hotez et al., 2008a, b; Budke et al., 2009). In this scenario, parasitologists from LAC countries have been working for more than a century, together with colleagues from all over the world, to contribute to a better understanding of the biology of these organisms and the diseases they cause, and to develop new tools for their diagnosis, treatment and control (see, for example, Mascarini, 2003; Verjovski-Almeida et al., 2003; Díaz et al., 2011a, b; Gazzinelli et al., 2012; Parkinson et al., 2012; Silva et al., 2012; Matoso et al., 2013; Morel et al., 2013; Sciutto et al., 2013; Tsai et al., 2013; Williams et al., 2013; Cooper et al., 2015; Oliveira \& Pierce, 2015; García et al., 2016; Koziol et al., 2016; Peón et al., 2016; McNulty et al., 2017).

Along these lines is the article on fasciolosis by Fasciola hepatica in South America. José Tort and Carlos Carmona (Universidad de la República, Uruguay) review the epidemiology of helminth infection in livestock and other hosts, and efforts to develop a single-antigen recombinant vaccine for ruminants. They also examine the important issue of drug resistance, which is compromising current control strategies worldwide. The review by Lilia Soler-Jiménez et al. (Centro de Investigación y Estudios Avanzados, CINVESTAV, Mexico) also concerns parasites affecting food production, notably finfish. The authors highlight that, while aquaculture has tripled over the past 20 years in Latin America, it is currently facing the problem of helminth infections. Noting that aquaculture mainly uses exotic species, and that parasites were brought into the region together with their hosts, they

*E-mail: cfernan@fq.edu.uy raise the point that the introduction of species for production purposes should be considered a breakdown in biosecurity, and be treated as such.

Two reviews analyse helminth diversity in different hosts. Leopoldina Aguirre-Macedo and colleagues (CINVESTAV, Mexico) review patterns of diversity in helminths infecting aquatic invertebrates in LAC. Given the availability of data, they focus on parasites affecting medically and economically important hosts (mainly snails, shrimps and crabs). Similarly, José Luis Luque (Universidade Federal Rural do Rio de Janeiro, Brazil) and colleagues analyse the diversity of helminth parasites from South American fishes. Both these articles emphasize the need of further studies to assess properly helminth diversity in the region.

The final two reviews focus on questions related to ecology and evolution. Victor Vidal-Martínez (CINVESTAV, Mexico) and Alison Wunderlich (University of London, UK) carried out a meta-analysis seeking evidence of a response of parasitic helminths to environmental damage and, therefore, whether helminths may be used as bioindicators of damage in the region. Interestingly, they found a low but significant indication of such a response and observed differences among parasite groups. Finally, Anindo Choudhury (St Norbert College, USA) together with Martín García-Varela and Gerardo Pérez-Ponce de León (CINVESTAV, Mexico) examined the extent to which adult helminths from freshwater fishes have been part of the Great American Biotic Interchange, finding that helminth interchange has been limited and asymmetrical.

Together, these reviews show that, in the LAC, helminthology is a thriving subject, with research directed at both important applied problems of the region and fundamental aspects of helminth ecology and evolution.

\section{References}

Budke, C.M., White, A.C. Jr \& García, H.H. (2009) Zoonotic larval cestode infections: neglected, neglected tropical diseases? PLoS Neglected Tropical Diseases 3, e319. 
Cooper, P.J., Chico, M.E., Platts-Mills, T.A., Rodrigues, L.C., Strachan, D.P. \& Barreto, M.L. (2015) Cohort profile: The Ecuador Life (ECUAVIDA) study in Esmeraldas Province, Ecuador. International Journal of Epidemiology 44, 1517-1527.

Díaz, A., Casaravilla, C., Irigoin, F., Lin, G., Previato, J. O. \& Ferreira, F. (2011a) Understanding the laminated layer of larval Echinococcus I: structure. Trends in Parasitology 27, 204-213.

Díaz, A., Casaravilla, C., Allen, J.E., Sim, R.B. \& Ferreira, A.M. (2011b) Understanding the laminated layer of larval Echinococcus II: immunology. Trends in Parasitology 27, 264-273.

García, H.H., Gonzalez, A.E., Tsang, V.C., O'Neal, S.E., Llanos-Zavalaga, F., Gonzalvez, G., Romero, J., Rodriguez, S., Moyano, L.M., Ayvar, V., Diaz, A., Hightower, A., Craig, P.S., Lightowlers, M.W., Gauci, C.G., Leontsini, E. \& Gilman, R.H. (2016) Elimination of Taenia solium transmission in northern Peru. New England Journal of Medicine 374, 2335-2344.

Gazzinelli, A., Correa-Oliveira, R., Yang, G.J., Boatin, B. A. \& Kloos, H. (2012) A research agenda for helminth diseases of humans: social ecology, environmental determinants, and health systems. PLoS Neglected Tropical Diseases 6, e1603.

Hotez, P.J., Bottazzi, M.E., Franco-Paredes, C., Ault, S.K. \& Periago, M.R. (2008a) The neglected tropical diseases of Latin America and the Caribbean: a review of disease burden and distribution and a roadmap for control and elimination. PLoS Neglected Tropical Diseases 2, e300.

Hotez, P.J., Brindley, P.J., Bethony, J.M., King, C.H., Pearce, E.J. \& Jacobson, J. (2008b) Helminth infections: the great neglected tropical diseases. Journal of Clinical Investigation 118, 1311-1321.

Koziol, U., Jarero, F., Olson, P.D. \& Brehm, K. (2016) Comparative analysis of Wnt expression identifies a highly conserved developmental transition in flatworms. BMC Biology 14, 10.

Mascarini, L.M. (2003) Uma abordagem histórica da trajetória da parasitologia. Ciência $\mathcal{E}$ Saúde Coletiva 8, 809-814.

Matoso, L.F., Oliveira-Prado, R., Abreu, M.N., Fujiwara, R.T., Loverde, P.T., Kloos, H., Gazzinelli, A. \& Correa-Oliveira, R. (2013) Longitudinal analysis of antigen specific response in individuals with Schistosoma mansoni infection in an endemic area of Minas Gerais, Brazil. Transactions of the Royal Society of Tropical Medicine and Hygiene 107, 797-805.

McNulty, S.N., Tort, J.F., Rinaldi, G., Fischer, K., Rosa, B.A., Smircich, P., Fontenla, S., Choi, Y.J., Tyagi, R., Hallsworth-Pepin, K., Mann, V.H., Kammili, L., Latham, P.S., Dell'Oca, N., Dominguez, F., Carmona, C., Fischer, P.U., Brindley, P.J. \& Mitreva, M. (2017) Genomes of Fasciola hepatica from the Americas reveal colonization with Neorickettsia endobacteria related to the agents of Potomac horse and human Sennetsu fevers. PLoS Genetics 13, e1006537.

Morel, N., Lassabe, G., Elola, S., Bondad, M., Herrera, S., Mari, C., Last, J.A., Jensen, O. \& González-Sapienza,
G. (2013) A monoclonal antibody-based copro-ELISA kit for canine echinococcosis to support the PAHO effort for hydatid disease control in South America. PLoS Neglected Tropical Diseases 7, e1967.

Oliveira, G. \& Pierce, R.J. (2015) How has the genomics era impacted schistosomiasis drug discovery? Future Medicinal Chemistry 7, 685-687.

Parkinson, J., Wasmuth, J., Salinas, G., Bizarro, C.V., Sanford, C., Berriman, M., Ferreira, H.B., Zaha, A., Blaxter, M., Maizels, R.M. \& Fernández, C. (2012) A transcriptomic analysis of Echinococcus granulosus larval stages: implications for parasite biology and host adaptation. PLoS Neglected Tropical Diseases 6, e1897.

Peón, A.N., Ledesma-Soto, Y. \& Terrazas, L.I. (2016) Regulation of immunity by Taeniids: lessons from animal models and in vitro studies. Parasite Immunology 38, 124-135.

Sciutto, E., Fragoso, G., Hernandez, M., Rosas, G., Martinez, J.J., Fleury, A., Cervantes, J., Aluja, A. \& Larralde, C. (2013) Development of the S3Pvac vaccine against porcine Taenia solium cysticercosis: a historical review. Journal of Parasitology 99, 686-692.

Silva, L.L., Marcet-Houben, M., Nahum, L.A., Zerlotini, A., Gabaldon, T. \& Oliveira, G. (2012) The Schistosoma mansoni phylome: using evolutionary genomics to gain insight into a parasite's biology. BMC Genomics 13,617 .

Tsai, I.J., Zarowiecki, M., Holroyd, N., Garciarrubio, A., Sanchez-Flores, A., Brooks, K.L., Tracey, A., Bobes, R. J., Fragoso, G., Sciutto, E., Aslett, M., Beasley, H., Bennett, H.M., Cai, J., Camicia, F., Clark, R., Cucher, M., De Silva, N., Day, T.A., Deplazes, P., Estrada, K., Fernandez, C., Holland, P.W., Hou, J., Hu, S., Huckvale, T., Hung, S.S., Kamenetzky, L., Keane, J. A., Kiss, F., Koziol, U., Lambert, O., Liu, K., Luo, X., Luo, Y., Macchiaroli, N., Nichol, S., Paps, J., Parkinson, J., Pouchkina-Stantcheva, N., Riddiford, N., Rosenzvit, M., Salinas, G., Wasmuth, J.D., Zamanian, M., Zheng, Y., Taenia solium Genome Consortium, Cai, X., Soberon, X., Olson, P.D., Laclette, J.P., Brehm, K. \& Berriman, M. (2013) The genomes of four tapeworm species reveal adaptations to parasitism. Nature 496, 57-63.

Verjovski-Almeida, S., DeMarco, R., Martins, E.A., Guimaraes, P.E., Ojopi, E.P., Paquola, A.C., Piazza, J. P., Nishiyama, M.Y. Jr, Kitajima, J.P., Adamson, R.E., Ashton, P.D., Bonaldo, M.F., Coulson, P.S., Dillon, G. P., Farias, L.P., Gregorio, S.P., Ho, P.L., Leite, R.A., Malaquias, L.C., Marques, R.C., Miyasato, P.A., Nascimento, A.L., Ohlweiler, F.P., Reis, E.M., Ribeiro, M.A., Sa, R.G., Stukart, G.C., Soares, M.B., Gargioni, C., Kawano, T., Rodrigues, V., Madeira, A. M., Wilson, R.A., Menck, C.F., Setubal, J.C., Leite, L. C. \& Dias-Neto, E. (2003) Transcriptome analysis of the acoelomate human parasite Schistosoma mansoni. Nature Genetics 35, 148-157.

Williams, D.L., Bonilla, M., Gladyshev, V.N. \& Salinas, G. (2013) Thioredoxin glutathione reductasedependent redox networks in platyhelminth parasites. Antioxidants and Redox Signaling 19, 735-745. 